\title{
EFFECT OF PARACETAMOL ON ANTIOXIDANT SYSTEM AND OSMOPROTECTANTS OF MUNG BEAN (VIGNA RADIATA)
}

\author{
ALMOHISEN, IBRAHEM A. A. \\ Shaqra University, College of Science and Humanitarian Studies, Qwaieah 11971, Saudi Arabia \\ (e-mail: ibraheem@su.edu.sa) \\ (Received 26 ${ }^{\text {th }}$ Dec 2018; accepted 20 $0^{\text {th }}$ Feb 2019)
}

\begin{abstract}
There is no report on panadol mediated changes in antioxidant system and osmoprotectants of Vigna radiata plants. An experiment was carried out to dissect the response of activities of antioxidant enzymes, stress biomarkers and proline accumulation in the presence of panadol in Vigna radiata plants. 10 days after germination, a range of panadol concentration $(0.0005,0.01,0.1 \mathrm{or} 1.0 \mathrm{ppm})$ was administered to the foliage of Vigna radiata plants, at the end of germination process (30 days from the beginning of germination) the plants were sampled to evaluate stress biomarkers, leaf water potential, antioxidant enzymes and proline content. The results demonstrate that the highest concentration of panadol was 1.0 ppm that induced oxidative stress that was noticeable via increasing levels of lipid peroxidation, and $\mathrm{H}_{2} \mathrm{O}_{2}$ accumulation in Vigna radiata plants. On the other hand, $0.1 \mathrm{ppm}$ of PD treatment modified the antioxidant system and the range of osmolytes to make the plants tolerate unfavorable conditions and helped to increase gross production through increasing photosynthetic activity.
\end{abstract}

Keywords: panadol, proline, mung bean, biomarker, stress physiology

\section{Introduction}

In the recent years, researchers have dissected out the role of pharmaceutical drugs and how they can affect target organs in the human body and how to make the drugs insistent so to maintain their chemical structure long enough to do their remedial work (Heberer, 2002; Kümmerer, 2004). However, the possible physiological and ecological influence of those compounds on non-target species or the environment are neglected (Hilton and Thomas, 2003). Therefore, the release of pharmaceuticals compounds in the environment is going to emerge as a great concern for both the ecosystem and human health (Kümmerer, 2004; Picó et al., 2017). Many prescribed drugs for humans are not completely absorbed by patients' body following intake, and approximately more than fifty percent of these are excreted as human waste to sewage systems in a nonbiodegradable form or degraded to only a certain extent (Breton and Boxall, 2003; Hilton and Thomas, 2003).

Panadol (Paracetamol/Acetaminophen; PD) which represents one of the most widespread pharmaceuticals in surface waters and sediments even after wastewater treatment in the world, has negative effects on humans, animals, microbes, and plants (Kümmerer, 2004; An et al., 2009). Kolpin et al. (2002) found that 10 USA streams are contaminated with PD at maximum concentrations up to $10 \mathrm{ppm}$. In Madinah City-Saudi Arabia alone, tons of PD had been dispensed by public hospitals and medical clinics in the year of 2009 (Shraim et al., 2017). Even though wastewater treatment plant may remove $80 \%$ of PD in the water, they are far from the negligible amount (Ternes, 1998, 2000; Heberer, 2002). Increased human population in Saudi Arabia also may increase the consumed and unused PD, which lead to steady continual increase of PD in the wastewater. Continual use of sewage sludge and reclaimed waters in irrigation may lead to increased concentration of Panadol in agricultural lands (Kümmerer, 2004; Alyemeni et al., 2014). 
Mung bean, Vigna radiata, Fabaceae, Vigna genus include about 150 species. One of the most important crop plants among these species is Vigna radiata with green seeds. Mung bean contains about $23.9 \%$ protein; rich in lysine which is generally low or deficient in cereals. Mature seeds are rich in proteins. The tender pods of mung bean are also consumed as vegetable (Agrawal et al., 2006). Its fast growth and sensitivity to abiotic stress make it suitable as a test subject to understood the phytotoxic effect of PD toward crop plant (Fariduddin et al., 2014).

In our previous study, we have found that varied concentrations of Panadol influences the photosynthetic efficiency of Vigna radiata plants in a concentration dependent manner (Al-Muwayhi, 2018; Almohisen, 2018). Therefore, it is essential to dissect out the behavior of antioxidant enzymes and osmoprotectants to unravel the panadol mediated changes in antioxidant systems and osmoprotectants.

\section{Materials and Methods}

\section{Growth conditions and analysis of various parameters}

Seeds source of Vigna radiata was from National Seed Corporation Ltd., New Delhi, India. Healthy seeds were decontaminated with $1 \%$ Chlorox $(\mathrm{NaOCl})$ for ten minutes, and then washed twice with distilled water. Panadol was used as the source of Paracetamol. It was acquired from Sigma Aldrich India Ltd. The stock solution of PD $(10 \mathrm{ppm})$ was obtained by dissolving the required amount $(0.0000005,0.00001,0.0001$ and $1 \mathrm{mg}$ ) of paracetamol in distilled water in a volumetric flask and the final volume was made up to the required volume. The required concentrations $(0.0005,0.01,0.1$ or $1.0 \mathrm{ppm}$ ) of PD were prepared by diluting stock solution and the concentrations of PD was based on the screening of various concentrations (Data unpublished). The seeds were sown in washed sand media, and allowed to germinate in growth chamber. The sand media kept moist using deionized water. When germination completed, the seedlings were irrigated with a solution of nutrients (Hewitt, 1966) every other day during the experimental period. At day $10^{\text {th }}$, the seedlings sprayed with deionized water (control), and $0.0005,0.01,0.1$ or $1.0 \mathrm{ppm}$ of PD for 10 days. Each seedling was speckled. The sprayer nozzle was adjusted to push out approximately $1 \mathrm{~mL}$ in one spray. Thus, each seedling received $3 \mathrm{~mL}$ of deionized water or PD treatement. The plants were grown under controlled conditions that is the average temperature ranged between $28 / 22^{\circ} \mathrm{C}$ day/night, maximum $75 \%$ relative humidity $(\mathrm{RH})$ at day and minimum $\mathrm{RH}$ was $65 \%$ at night, and the photoperiod was 14 hour. Irrigation was applied with deionized water and nutrient solution on every other day. Harvesting of plants began at 30 days stage to estimate the chlorophyll content, net photosynthetic rate, maximum quantum yield of PSII and related attributes. The experimental design was completely randomized block design (CRB). Total cups were 25 , cup size was $350 \mathrm{~mL}$, each cup contained three plant and replicated five times. The replication of treatment was five times. The leaf water potential (LWP) was measured in the fully expanded leaves of the plant using Psypro Water Potential System (Wescor, Inc. 370 West 1700 South Logan, Utah 84321, USA).

Estimation of Lipid peroxidation rates was performed with the measurement of the malondialdehyde equivalents as described by Hodges et al. (1999). 80\% ethanol was used to homogenize $0.5 \mathrm{~g}$ of the leaf. Then the homogeneous sample was centrifuged at $3000 \mathrm{~g}$ for 10 minutes under $4^{\circ} \mathrm{C}$ temperatures. The pellet was extracted twice with the 
same solvent. $1 \mathrm{~mL}$ of supernatant was added to a test tube containing the same volume of a solution of $20 \%$ trichloroacetic acid, $0.01 \%$ butylated hydroxy toluene and $0.65 \%$ thiobarbutyric acid.

Samples were heated for $25 \mathrm{~min}$ at $95^{\circ} \mathrm{C}$, and then cooled down to $24 \pm 1^{\circ} \mathrm{C}$. Wavelengths of 440, 532 and $600 \mathrm{~nm}$ were used to measure absorbance of the samples. The formula of Hodges et al. (1999) was used to calculate Lipid peroxidation rates equivalent (nano mole malondialdehyde $\mathrm{mL}^{-1}$ ).

The accumulation of hydrogen peroxide was estimated according to the method explained by Jana and Choudhuri (1982). $500 \mathrm{mg}$ from samples was homogenized in $3.0 \mathrm{~mL}$ of phosphate buffer $(50 \mathrm{mM}$ and $\mathrm{pH} 6.8)$. Then the homogeneous sample was centrifuged for 25 minutes at $6000 \mathrm{~g}$.

$3.0 \mathrm{~mL}$ from the extract was mixed with $0.1 \%$ titanium chloride in $20 \%$ (v/v) sulphuric acid, the mixture was centrifuged at $6000 \mathrm{~g}$ for 15 minutes. A spectrophotometer was used for the measurement of color absorbance at $410 \mathrm{~nm}$, and the color absorbance was compared with that of the calibration curve. The standard curve of known concentration of $\mathrm{H}_{2} \mathrm{O}_{2}$ was used to compute $\mathrm{H}_{2} \mathrm{O}_{2}$ content on fresh mass basis. $0.5 \mathrm{~g}$ from leaf was homogenized in $50 \mathrm{mM}$ phosphate buffer $(\mathrm{pH} 7.0)$ containing $1 \%$ polyvinylpyrrolidone, for the assessment of antioxidant enzymes. The homogeneous sample was centrifuged for 10 minutes at $27600 \mathrm{~g}$ under a temperature of $4^{\circ} \mathrm{C}$, the supernatant was used as the source of catalase, peroxidase and superoxide dismutase enzymes. The procedure described by Chance and Maehly (1955) was followed to assay Peroxidase and catalase. Catalase was measured by titrating the reaction mixture consisting of phosphate buffer ( $\mathrm{pH} \mathrm{6.8),} 0.1 \mathrm{M} \mathrm{H}_{2} \mathrm{O}_{2}$, enzyme extract and $2 \% \mathrm{H}_{2} \mathrm{SO}_{4}$, against solution of $0.1 \mathrm{~N}$ potassium permagnate. The reaction mixture for peroxidase consisted of pyragallol, phosphate buffer $\left(\mathrm{pH} \mathrm{6.8),1 \%} \mathrm{H}_{2} \mathrm{O}_{2}\right.$ and enzyme extract. Change in absorbance caused by catalytic conversion of pyragallol to purpurogallin, was noticed at an interval time of 20 second and 2 minutes, at wavelength $420 \mathrm{~nm}$ on a spectrophotometer. Control set was prepared by using distilled water as an alternative of enzyme extract. The activity of superoxide dismutase was computed by estimating its capability to inhibit the photochemical reduction of nitroblue tetrazolium by following Beauchamp and Fridovich (1971). The reaction mixture contained $50 \mathrm{mM}$ phosphate buffer ( $\mathrm{pH} 7.8$ ), $13 \mathrm{mM}$ methionine, $75 \mathrm{mM}$ nitroblue tetrazolium, $2 \mathrm{mM}$ riboflavin, $0.1 \mathrm{mM}$ EDTA and $0-50 \mathrm{~mL}$ enzyme extract and was situated under $15 \mathrm{~W}$ fluorescent lamp. The reaction began by switch on the light and run for 10 minutes. The reaction was stopped by switching off the light. 50\% inhibition by light was considered as one enzyme unit. The estimation of proline content in fresh leaves samples was carried out according to Bates et al. (1973). Sulphosalicylic acid was used for sample extraction. Equivalent volume of glacial acetic acid and ninhydrin solutions were added to the extracted sample. The mixture was boiled at $100^{\circ} \mathrm{C}$ after adding $5 \mathrm{~mL}$ of toluene. The toluene layer absorption was recorded at $528 \mathrm{~nm}$ wavelength on a spectrophotometer.

\section{Statistical analysis}

Data were analyzed by using SPSS, 17.0 for Windows (SPSS, Chicago, IL, USA). Analysis of variance (ANOVA) was achieved to examine vitiations between treatments at $\mathrm{P}<0.05$, least significant difference (LSD) was used for comparison of the means. 


\section{Results}

\section{Lipid peroxidation ( $\mathrm{LPO}$ ), $\mathrm{H}_{2} \mathrm{O}_{2}$ content and leaf water potential}

It is evident from Table 1 that LPO and $\mathrm{H}_{2} \mathrm{O}_{2}$ accumulation in plant leaves significantly increased with increasing of PD concentration. Plants treated by $1.0 \mathrm{ppm}$ of PD accumulated 27.96 and $24.95 \%$ LPO and $\mathrm{H}_{2} \mathrm{O}_{2}$, respectively, as compared to control plants. However, plants treated by $1.0 \mathrm{ppm}$ of PD accumulated higher content of LPO than $\mathrm{H}_{2} \mathrm{O}_{2}$. The plants treated by $0.005,0.01,0.1$ or $1.0 \mathrm{ppm}$ of PD had varied leaf water potential compared with control plants in a concentration dependent manner and maximum increase was noted at $0.1 \mathrm{ppm}$ of PD (Table 1) whereas the minimum increase was noted at $1.0 \mathrm{ppm}$ of PD.

Table 1. Effect of panadol (PD; 0.005, 0.01, 0.1, or 1.0 ppm) induced changes on lipid peroxidation, $\mathrm{H}_{2} \mathrm{O}_{2}$ content and leaf water potential of Vigna radiata 30 days after sowing

\begin{tabular}{|c|c|c|c|}
\hline Treatment & $\begin{array}{l}\text { Lipid peroxidation } \\
\quad\left(\mathrm{n} \mathrm{mol} \mathrm{g} \mathrm{g}^{-1} \mathrm{FM}\right)\end{array}$ & $\begin{array}{l}\mathrm{H}_{2} \mathrm{O}_{2} \text { content } \\
\left(\mathrm{n} \mathrm{mol} \mathrm{g^{-1 }} \text { FM) }\right.\end{array}$ & $\begin{array}{c}\text { Leaf water potential } \\
\text { (-MPa) }\end{array}$ \\
\hline Control & $8.01 \pm 0.11 \mathrm{c}$ & $5.01 \pm 0.05 \mathrm{c}$ & $-0.84 \pm 0.01 b$ \\
\hline $\mathrm{PD}(0.005)$ & $8.15 \pm 0.10 \mathrm{c}$ & $5.12 \pm 0.06 \mathrm{c}$ & $-0.77 \pm 0.01 \mathrm{c}$ \\
\hline $\mathrm{PD}(0.01)$ & $8.97 \pm 0.14 b$ & $5.81 \pm 0.05 \mathrm{~b}$ & $-0.69 \pm 0.02 \mathrm{~d}$ \\
\hline $\mathrm{PD}(0.1)$ & $9.21 \pm 0.15 b$ & $5.61 \pm 0.06 \mathrm{~b}$ & $-0.63 \pm 0.01 \mathrm{e}$ \\
\hline PD (1.00) & $10.25 \pm 0.09 \mathrm{a}$ & $6.26 \pm 0.05 \mathrm{a}$ & $-0.92 \pm 0.02 \mathrm{a}$ \\
\hline LSD & 0.42 & 0.27 & 0.03 \\
\hline Significannce level & $* * *$ & $* * *$ & $* *$ \\
\hline$F$-value & 117.13 & 119.99 & 137.77 \\
\hline
\end{tabular}

$$
\begin{aligned}
& * * \mathrm{P}<0.01 \\
& * * * \mathrm{P}<0.001
\end{aligned}
$$

\section{Proline and sugar content}

The leaf proline and sugar content significantly increased with increasing concentrations of PD $(0.005,0.01,0.1$ or $1.0 \mathrm{ppm})$ but $1.0 \mathrm{ppm}$ showed the highest increase of proline and sugar content by $29.95 \%$ and $25.96 \%$, respectively, in comparison to control plant contents. Also catalase activity was increased by $31.87 \%$ and $24.49 \%$ in plants treated by 0.1 and $1.0 \mathrm{ppm} \mathrm{PD}$, respectively, as compared to control plants (Table 2).

Table 2. Effect of panadol (PD; 0.005, 0.01, 0.1, or $1.0 \mathrm{ppm}$ ) induced changes on proline

\begin{tabular}{|c|c|c|}
\hline Treatment & $\begin{array}{l}\text { Proline content } \\
\left(\mu \text { mol } \mathrm{g}^{-1} \mathrm{FM}\right)\end{array}$ & $\begin{array}{l}\text { Sugar content } \\
\left(\mathrm{mg} \mathrm{g}^{-1} \text { FM) }\right.\end{array}$ \\
\hline Control & $8.98 \pm 0.10 \mathrm{e}$ & $25.11 \pm 0.04 \mathrm{~d}$ \\
\hline $\mathrm{PD}(0.005)$ & $9.96 \pm 0.14 \mathrm{~d}$ & $28.12 \pm 0.03 \mathrm{c}$ \\
\hline $\mathrm{PD}(0.01)$ & $10.68 \pm 0.15 \mathrm{c}$ & $29.12 \pm 0.05 b c$ \\
\hline $\mathrm{PD}(0.1)$ & $11.67 \pm 0.07 \mathrm{a}$ & $31.63 \pm 0.04 \mathrm{a}$ \\
\hline PD (1.00) & $11.13 \pm 0.08 \mathrm{~b}$ & $30.13 \pm 0.02 b$ \\
\hline LSD & 0.52 & 1.04 \\
\hline Significance level & $* * *$ & $* *$ \\
\hline$F$-value & 132.65 & 154.12 \\
\hline
\end{tabular}
content, sugar content and catalase activity of Vigna radiata 30 days after sowing 


\section{Activities of antioxidants enzymes CAT, POX, and SOD}

PD significantly affect the antioxidant enzyme activities (catalase/CAT, peroxidase/POX, and super oxide dismutase/SOD) in all plants treated by the PD, and the three enzyme activities increased with the increasing level of PD. The highest enzyme activities were recorded in plants treated by $0.1 \mathrm{ppm}$ PD (Table 3). The highest activity rate for CAT, POX, and SOD were recorded at $0.1 \mathrm{ppm}$ of PD in Vigna radiata plants demonstrating increases of $24.94 \%, 21.92 \%$, and $17.51 \%$, respectively, in comparison to the control plants.

Table 3. Effect of panadol (PD; 0.005, 0.01, 0.1, or 1.0 ppm) induced changes on catalase, peroxidase activity, and superoxide dismutase activity of Vigna radiata 30 days after sowing

\begin{tabular}{|c|c|c|c|}
\hline Treatment & $\begin{array}{c}\text { Catalase activity } \\
\left(\mathrm{m} \text { mol L }{ }^{-1} \mathrm{H}_{2} \mathrm{O}_{2}\right. \\
\left.\text { decomposed } \mathrm{g}^{-1} \mathrm{FM}\right)\end{array}$ & Peroxidase activity & $\begin{array}{c}\text { Superoxide dismutase } \\
\text { activity }\end{array}$ \\
\hline Control & $298 \pm 1.10 \mathrm{~d}$ & $10.90 \pm 0.10 \mathrm{e}$ & $177 \pm 1.75 \mathrm{~d}$ \\
\hline $\mathrm{PD}(0.005)$ & $327 \pm 2.10 \mathrm{c}$ & $12.20 \pm 0.12 \mathrm{~d}$ & $196 \pm 1.95 \mathrm{c}$ \\
\hline $\mathrm{PD}(0.01)$ & $357 \pm 2.22 \mathrm{~b}$ & $12.82 \pm 0.11 \mathrm{c}$ & $205 \pm 1.92 \mathrm{bc}$ \\
\hline $\mathrm{PD}(0.1)$ & $393 \pm 2.59 \mathrm{a}$ & $13.95 \pm 0.13 \mathrm{a}$ & $221 \pm 2.00 \mathrm{a}$ \\
\hline PD (1.00) & $371 \pm 3.09 \mathrm{~b}$ & $13.29 \pm 0.14 b$ & $208 \pm 1.99 \mathrm{~b}$ \\
\hline LSD & 11.9 & 0.46 & 9.09 \\
\hline Significance level & $* * *$ & $* * *$ & $* *$ \\
\hline$F$-value & 111.11 & 124.76 & 121.21 \\
\hline
\end{tabular}

\section{Discussion}

Lipid peroxidation and $\mathrm{H}_{2} \mathrm{O}_{2}$ accumulation are considered biochemical markers for the free radical attributed injury under different environmental cues and external stimuli (Verma and Dubey, 2003). Furthermore, these biochemical processes are commonly defined by increasing formation of reactive oxygen species (ROS) (Foryer and Noctor, 2000; Gill and Tuteja, 2010). The results of this study, confirmed and verified this phenomenon, as our results showed an increasing accumulation level of lipid peroxidation, and $\mathrm{H}_{2} \mathrm{O}_{2}$ at the highest concentration (1 ppm) of PD (Table 1).

Therefore, it could be assumed that higher concentration would be toxic to Vigna radiata plants and lead to excess production of reactive oxygen species (ROS). ROS in plant tissues are regulated by plant antioxidant systems or antioxidant enzymes such as Catalase, Peroxidase, and Superoxide dismutase (Schutzendubel, 2002) as well as osmoprotectants i.e. proline (Szabados and Savouré, 2010). The present study revealed that treatment of plants with $0.1 \mathrm{ppm}$ of PD boosted the activity of antioxidant enzymes (CAT, POX and SOD; Tables 2 and 3) along with the level of proline accumulation (Table 2). In the similar line with An et al. (2009) who found that the activities of peroxidase and superoxide dismutase significantly increased in the wheat plant when exposed to paracetamol in a duration dependent manner. Proline increase plant stress tolerance by maintaining NADPH/NADP ${ }^{+}$balance, GSH levels, and during infection, drives the oxidative rupture of the hypersensitive response (Miller et al., 2009; Ben Rejeb et al., 2014). As Szabados and Savouré (2010) confirmed proline as a signaling molecule to modest mitochondrial functions, and it activates specific gene expression that could be 
necessary for plant recovery in stress conditions. The findings of this study are in consistence with these previous studies, as this study showed that presence of PD significantly increased the proline accumulation and sugar content (Table 2). With cumulative effort of enhanced antioxidant system and proline accumulation under exogenously sourced PD i.e. paracetamol enhanced tolerance capacity of Vigna radiata plants to withstand various environment cues and helped in increasing their gross production.

In this study, we determined that the limit of PD in rivers and agricultural irrigation systems should be less than $1 \mathrm{ppm}$ to decrease the negative effect of PD on mung bean plantation. Environmental Protection Agency and Saudi Government may use this limit as one of the allowable pharmaceutical water quality standard for the protection of the plant.

\section{Conclusions}

The highest concentration of panadol that induced oxidative stress was $1.0 \mathrm{ppm}$ that was obvious through increased levels of lipid peroxidation, and $\mathrm{H}_{2} \mathrm{O}_{2}$ accumulation in Vigna radiata plants. On the other hand, $0.1 \mathrm{ppm}$ of $\mathrm{PD}$ treatment improved the antioxidant system and the level of osmolytes to make the plants tolerate unfavorable conditions and helped in the increase of gross production through increasing the photosynthetic activity.

\section{REFERENCES}

[1] Agrawal, M., Singh, B., Agrawal, S., Bell, J., Marshall, F. (2006): The effect of air pollution on yield and quality of mung bean grown in peri-urban areas of Varanasi. - Water, Air, and Soil Pollution 169: 239-254.

[2] Al-Muwayhi, M. A. R. (2018): Paracetamol mediated changes modifies the photosynthetic efficiency of Vigna radiata. - Legume Research: An International Journal 41.

[3] Almohisen, I. A. (2018): Effect of increasing concentration of paracetamol on performance of Vigna radiata: A concentration dependent study. - Legume Research 41: 895-898.

[4] Alyemeni, M. N., Wijaya, L., Hayat, S. (2014): Physico-Chemical and Heavy Metal Status of Wastewater and Sediment of Wadi Hanifah (Riyadh, Saudi Arabia): A Case Study. Fresen. Environ. Bull 23: 130-137.

[5] An, J., Zhou, Q., Sun, F., Zhang, L. (2009): Ecotoxicological effects of paracetamol on seed germination and seedling development of wheat (Triticum aestivum L.). - Journal of Hazardous Materials 169: 751-757.

[6] Bates, L. S., Waldren, R. P., Teare, I. D. (1973): Rapid determination of free proline for water-stress studies. - Plant and Soil 39: 205-207.

[7] Beauchamp, C., Fridovich, I. (1971): Superoxide dismutase: Improved assays and an assay applicable to acrylamide gels. - Analytical Biochemistry 44: 276-287.

[8] Ben Rejeb, K., Abdelly, C., Savouré, A. (2014): How reactive oxygen species and proline face stress together. - Plant Physiology and Biochemistry 80: 278-284.

[9] Breton, R., Boxall, A. (2003): Pharmaceuticals and personal care products in the environment: regulatory drivers and research needs. - QSAR \& Combinatorial Science 22: 399-409.

[10] Chance, B., Maehly, A. C. (1955): Assay of catalases and peroxidases. - Methods in Enzymology. Elsevier.

[11] Fariduddin, Q., Yusuf, M., Ahmad, I., Ahmad, A. (2014): Brassinosteroids and their role in response of plants to abiotic stresses. - Biologia Plantarum 58: 9-17. 
[12] Foryer, C., Noctor, G. (2000): Oxygen processing in photosynthesis: regulation and signaling. - New Phytol 146: 359-388.

[13] Gill, S. S., Tuteja, N. (2010): Reactive oxygen species and antioxidant machinery in abiotic stress tolerance in crop plants. - Plant Physiology and Biochemistry 48: 909-930.

[14] Heberer, T. (2002): Occurrence, fate, and removal of pharmaceutical residues in the aquatic environment: a review of recent research data. - Toxicology Letters 131: 5-17.

[15] Hewitt, E. J. (1966): Sand and water culture methods used in the study of plant nutrition. Farnham Royal (England), Commenwealth Agricultural Bureaux.

[16] Hilton, M. J., Thomas, K. V. (2003): Determination of selected human pharmaceutical compounds in effluent and surface water samples by high-performance liquid chromatography-electrospray tandem mass spectrometry. - Journal of Chromatography A 1015: 129-141.

[17] Hodges, D. M., Delong, J. M., Forney, C. F., Prange, R. K. (1999): Improving the thiobarbituric acid-reactive-substances assay for estimating lipid peroxidation in plant tissues containing anthocyanin and other interfering compounds. - Planta 207: 604-611.

[18] Jana, S., Choudhuri, M. A. (1982): Glycolate metabolism of three submersed aquatic angiosperms during ageing. - Aquatic Botany 12: 345-354.

[19] Kolpin, D. W., Furlong, E. T., Meyer, M. T., Thurman, E. M., Zaugg, S. D., Barber, L. B., Buxton, H. T. (2002): Pharmaceuticals, hormones, and other organic wastewater contaminants in US streams, 1999- 2000: A national reconnaissance. - Environmental science \& technology 36: 1202-1211.

[20] Kümmerer, K. (2004): Pharmaceuticals in the environment: sources, fate, effects and risks. - Berlin, Springer.

[21] Miller, G., Honig, A., Stein, H., Suzuki, N., Mittler, R., Zilberstein, A. (2009): Unraveling $\Delta$ 1-Pyrroline-5-Carboxylate-Proline Cycle in Plants by Uncoupled Expression of Proline Oxidation Enzymes. - Journal of Biological Chemistry 284: 26482-26492.

[22] Picó, Y., Alvarez-Ruiz, R., Wijaya, L., Alfarhan, A., Alyemeni, M., Barceló, D. (2017): Analysis of ibuprofen and its main metabolites in roots, shoots, and seeds of cowpea (Vigna unguiculata L. Walp) using liquid chromatography-quadrupole time-of-flight mass spectrometry: uptake, metabolism, and translocation. - Analytical and bioanalytical chemistry: $1-14$.

[23] Schutzendubel, A. (2002): Plant responses to abiotic stresses: heavy metal-induced oxidative stress and protection by mycorrhization. - Journal of Experimental Botany 53: 1351-1365.

[24] Shraim, A., Diab, A., Alsuhaimi, A., Niazy, E., Metwally, M., Amad, M., Sioud, S., Dawoud, A. (2017): Analysis of some pharmaceuticals in municipal wastewater of Almadinah Almunawarah. - Arabian Journal of Chemistry 10: S719-S729.

[25] Szabados, L., Savouré, A. (2010): Proline: a multifunctional amino acid. - Trends in Plant Science 15: 89-97.

[26] Ternes, T. A. (1998): Occurrence of drugs in German sewage treatment plants and rivers. - Water research 32: 3245-3260.

[27] Ternes, T. (2000): Pharmaceuticals and metabolites as contaminants of the aquatic environment: An overview. - Abstracts of Papers of the American Chemical Society, Washington, DC.

[28] Verma, S., Dubey, R. S. (2003): Lead toxicity induces lipid peroxidation and alters the activities of antioxidant enzymes in growing rice plants. - Plant Science 164: 645-655. 